\title{
Trophic biology of Stylophora pistillata larvae: evidence from stable isotope analysis
}

\author{
Ada Alamaru ${ }^{1,2, *}$, Ruth Yam $^{3}$, Aldo Shemesh ${ }^{3}$, Yossi Loya ${ }^{1}$ \\ ${ }^{1}$ Department of Zoology, George S. Wise Faculty of Life Sciences, Tel Aviv University, Tel Aviv 69978, Israel \\ ${ }^{2}$ The Interuniversity Institute for Marine Sciences at Eilat (IUI), PO Box 469, Eilat 88103, Israel \\ ${ }^{3}$ Department of Environmental Sciences and Energy Research, Weizmann Institute of Science, PO Box 26, \\ Rehovot 76100, Israel
}

\begin{abstract}
The successful recruitment of planktonic larvae to coral reefs is essential for the continued existence of these highly diverse ecosystems. Feeding strategies may affect recruitment success and potentially determine species distribution by controlling the dispersal range of the larvae. Our aim here was to ascertain the feeding strategies of planula larvae of the coral Stylophora pistillata by using stable isotopes. Planula larvae, fragments of parental colonies, and 3 potential food types were analyzed for carbon and nitrogen stable isotope compositions and $\mathrm{C} / \mathrm{N}$ ratios. We found that planulae were depleted in ${ }^{13} \mathrm{C}$ when compared to parental tissues, whereas their $\mathrm{C} / \mathrm{N}$ ratios were 2 -fold higher. Following lipid extraction, there were no significant differences in $\delta^{13} \mathrm{C}$ values and C/N ratios between lipid-free planulae and parental colonies. This indicates that the differences in $\delta^{13} \mathrm{C}$ originate in the lipid content of the planulae and not from any isotopic fractionation that may occur during embryological development. Controlled feeding experiments were conducted using phytoplankton, zooplankton, and bacteria. Despite the presence of an oral opening, the planulae did not show any feeding behavior, and the stable isotope data corroborated the observations of no feeding. Moreover, following $2 \mathrm{wk}$ of starvation in the dark, planulae started to utilize their lipid and protein reservoirs. These results stress the importance of the photosynthates translocated from the algal symbionts to these planulae as an energy source.
\end{abstract}

KEY WORDS: Larval biology $\cdot$ Stylophora pistillata $\cdot$ Lipids $\cdot$ Coral nutrition $\cdot$ Red Sea

Resale or republication not permitted without written consent of the publisher

\section{INTRODUCTION}

World wide, coral reefs are experiencing substantial degradation due to both natural (e.g. storms, catastrophic low tide events) and anthropogenic stresses (e.g. pollution, over-fishing, terrestrial runoff) (Wilkinson 1999). The importance of larval recruitment for the persistence and survival of tropical marine communities is thus immense. Despite the fact that reefs are built in large part by the growth of existing corals through cloning, sexual reproduction is a very important process in the replenishment of degraded reefs (Pennisi 2007). Because coral larvae are planktonic and serve as 'dispersion vehicles' for genes (Amar et al. 2007), these stages are critical for preserving diversity and enabling corals to survive in a rapidly changing world. Larval feeding behaviors have a strong effect on recruitment success and therefore can potentially determine adult population distribution and abundance (Olson \& Olson 1989).

Over the past few decades, considerable research has been dedicated to investigating life history traits of coral larvae. For example, studies have been performed on substratum preferences (Harrigan 1972, Lewis 1974, Golbuu \& Richmond 2007), the initiation of symbiosis with zooxanthellae (Benayahu et al. 1989, van Oppen 2001, deBoer et al. 2007, Hirose et al. 2008), reproductive timing and regulation (Levy et al. 2007), the effects of temperature on fertilization success and larval physiology (Edmunds et al. 2001, Baird et al. 
2006, Nozawa \& Harrison 2007), ultraviolet radiation effects on larvae (Gleason et al. 2006), and effects of different pollutants on coral reproduction and larvae (Negri et al. 2005). However, questions remain in the field of larval biology of corals, particularly pertaining to the trophic biology of larvae and the relationships between the reproductive strategies of corals and their larval feeding behavior.

In general, marine invertebrates can have planktotrophic (feeding), lecithotrophic (yolk laden nonfeeding), or mixotrophic larvae. These larval types can differ in size, longevity, and competence period, which will affect the dispersal range of the species (Shlesinger \& Loya 1985, Strathmann 1985). Planktotrophic larvae of marine invertebrates develop from eggs that contain material that is sufficient to support complete development but insufficient to support their metamorphosis into juveniles (Strathmann 1985). The acquisition of particulate or dissolved food through an oral opening or acquisition of photosynthates from photosynthetic symbionts is necessary to fuel successful completion of development and metamorphosis. In contrast, lecithotrophic larvae develop from larger eggs and do not require exogenous food for development and metamorphosis (McEdward 1997). To date, the nutritive aspects of coral larvae have hardly been explored. It was assumed that coral larvae are lecithotrophic and do not feed until after settlement and metamorphosis (Harrigan 1972). Other coral researchers (Rinkevich \& Loya 1979, Richmond 1985) reported that coral planulae engulf food particles through their oral pore; however, this assumption has never been critically examined.

The main objective of the current research was to study the trophic biology of coral larvae by identifying the carbon and nitrogen sources and their relative contribution to coral larval metabolism. Specifically, we tested the contribution of the algal symbionts to larval metabolism versus that of extrinsic sources by using stable isotope analysis. In addition, we aimed to describe the isotopic variability of carbon and nitrogen in parental coral colonies and their larvae, and to examine whether isotopic fractionation occurs in coral larvae during embryological development.

\section{MATERIALS AND METHODS}

The hermatypic (reef-building) coral Stylophora pistillata (Esper, 1797) (family Pocilloporidae) was chosen as a model species in this work, as it is the most common branching coral in the Gulf of Aqaba (Loya 1972). It is a brooder that reproduces from winter to spring, from January to July, and releases positively buoyant planula larvae (1 to $3 \mathrm{~mm}$ length) already containing symbiotic zooxanthellae (Rinkevich \& Loya 1979). The larvae are well developed, having an oral pore $(\sim 0.1 \mathrm{~mm})$ that opens to a gastrovascular cavity and can undergo metamorphosis a few hours after being released (Loya 1976, Rinkevich \& Loya 1979).

Sample preparation. Planulae and parental corals were sampled by SCUBA from $2 \mathrm{~m}$ and $20 \mathrm{~m}$ depth during the major reproductive season of the species, from February to May 2007, in front of the Interuniversity Institute for Marine Sciences at Eilat (IUI; $29^{\circ} 30.05^{\prime} \mathrm{N}$, $34^{\circ} 55^{\prime}$ E). Planula larvae were collected from parental colonies using plankton traps (120 $\mu \mathrm{m}$ mesh) placed over the colonies at sunset and removed early in the morning (Rinkevich \& Loya 1979, Zakai et al. 2006). Each gravid colony we sampled was measured, and a nubbin was taken for stable isotope analysis. Immediately after collection, the parental colony samples and their planulae were rinsed with $0.2 \mu \mathrm{m}$ filtered sea water (FSW) in order to remove all particles and debris, and immediately frozen at $-80^{\circ} \mathrm{C}$ until further analysis. In all cases, the planulae were run as bulk (i.e. the algal fraction was not separated from the animal tissue), while adult coral tissue was separated into 2 fractions: the animal and algal fractions. Preliminary experiments confirmed that there were no significant differences between bulk planulae, animal fraction, and algal fraction isolated from the planulae. For isotopic analysis, we pooled 10 planulae, sampled from the same colony on the same date, as 1 sample. Each sample was homogenized, concentrated on pre-combusted $25 \mathrm{~mm}$ GF/F filters ( $0.7 \mu \mathrm{m}$ pore size), and dried in the oven at $60^{\circ} \mathrm{C}$. The coral tissue was removed from the skeleton using an air-brush system (PAASCHE) with FSW. Homogenized tissue was then centrifuged at $615 \times g$ for 5 min at $4^{\circ} \mathrm{C}$ to precipitate most of the zooxanthellae. The supernatant was transferred to a new labeled tube and centrifuged twice more at $3850 \times g$ to precipitate residual algae. To avoid tissue contamination of the pellets, the zooxanthellae were re-suspended, washed, and centrifuged again at $3850 \times g$ twice more. The pellets were decalcified by adding $0.5 \mathrm{ml}$ of $\mathrm{HCl}(1 \mathrm{~N})$ to remove all carbonates from the sample (Muscatine et al. 1989). The coral zooxanthellae were transferred to Eppendorf tubes, and the coral tissue was concentrated and filtered on pre-combusted $47 \mathrm{~mm}$ GF/F filters (Muscatine et al. 1989, Rosenfeld 2004). All samples, including filters and bulk zooxanthellae in Eppendorf tubes, were washed with double-distilled water (DDW) in order to wash out the salts and then dried at $60^{\circ} \mathrm{C}$ for further isotopic analysis.

Lipid extraction. For the analysis of lipid-free samples, 50 planulae originating from the same colony were pooled and considered as 1 sample (including both tissue and algal symbionts). The lipid fraction was extracted from coral samples and planulae 3 consecu- 
tive times in 2:1 (v/v) chloroform:methanol (extraction solution) to ensure removal of the entire lipid fraction (Folch et al. 1957). Each coral nubbin, about $3.5 \mathrm{~cm}$ in length, was immersed in $30 \mathrm{ml}$ of extraction solution in capped $50 \mathrm{ml}$ tubes. Planulae were immersed in $10 \mathrm{ml}$ of extraction solution in capped $15 \mathrm{ml}$ tubes. Following lipid removal, the samples were rinsed with DDW. Lipid-free nubbins were air-brushed (PAASCHE) with DDW to separate the tissue from the skeleton. All lipidfree samples (i.e. coral tissues and planulae) were homogenized and concentrated on $25 \mathrm{~mm}$ pre-combusted GF/F filters and dried in the oven at $60^{\circ} \mathrm{C}$.

Effect of light on nutrition of Stylophora pistillata planulae. To test the contribution of photosynthates translocated by the symbiotic zooxanthellae to the planulae, we maintained the planulae for a period of 2 wk under light and dark conditions (i.e. normal light regime versus complete darkness). To prevent biofilm development, which is a settlement cue for coral larvae, we used sterile Petri dishes filled with $0.2 \mu \mathrm{m}$ FSW. Planulae were collected from shallow-water coral colonies and immediately transferred to glass Petri dishes filled with $30 \mathrm{ml}$ of FSW. For each treatment (light and dark) we used 4 replicates, each containing 30 planulae. The Petri dishes were maintained in the laboratory (room temperature $=25^{\circ} \mathrm{C}$ ) under ambient illumination (approximately $300 \mu \mathrm{mol}$ photons $\mathrm{m}^{-1} \mathrm{~s}^{-1}$ ). Dark conditions were achieved by using aluminum foil to completely cover the Petri dishes. The medium was changed every other day with fresh FSW under red light.

Feeding experiments. To test whether Stylophora pistillata planulae actively feed during their planktonic phase, we conducted controlled feeding experiments. The planulae used for the feeding experiments were first rinsed with FSW and then placed in aerated $500 \mathrm{ml}$ glass containers filled with FSW until used. To avoid a mix of planulae of different developmental stages, we chose planulae that were both elongated and swimming. These were divided into glass Petri dishes filled with $30 \mathrm{ml}$ of FSW. We used 30 planulae in pre-washed and autoclaved dishes. Planulae were allowed to acclimate for $1 \mathrm{~d}$ at room temperature $\left(25^{\circ} \mathrm{C}\right)$ under ambient light conditions (approximately 300 $\mu \mathrm{mol}$ photons $\mathrm{m}^{-1} \mathrm{~s}^{-1}$ ) without food. The planulae were subjected to 3 different feeding treatments (3 dishes for each treatment): (1) Nannochloropsis sp., a unicellular green alga $2.5 \mu \mathrm{m}$ in size, widely used in the aquaculture industry for feeding small zooplankton, (2) Brachionus rotundiformis, a rotifer with $180 \mu \mathrm{m}$ lorica length, widely used in tropical aquaculture for the first feeding of fish larvae with small mouth openings $(<100$ $\mu \mathrm{m})$, and (3) Photobacterium leiognathi, a bioluminescent bacterium isolated from the Red Sea (Yetinson \& Shilo 1979). These feeding treatments were chosen for
2 reasons: (1) homogeneity of the isotopic signal (i.e. use of organisms that were cultured under the same set of conditions and had the same isotopic signal), and (2) small size (i.e. no larger than the larval oral pore). Petri dishes without food additives were used as controls. Three different Petri dishes were used for each feeding treatment and control $(\mathrm{n}=3)$.

Each day the planulae were incubated for $2 \mathrm{~h}$ at room temperature with the tested food sources and then transferred to clean dishes filled with fresh FSW. Each feeding experiment was run for $2 \mathrm{wk}$, except the bacteria treatment, which was run for $24 \mathrm{~h}$. The planulae were incubated with the bacteria for $30 \mathrm{~min}$ and then washed with FSW. The reason for the short exposure time in the bacteria treatment is that the presence of bacteria and bacterial biofilms enhance coral larval metamorphosis and settlement (Webster et al. 2004).

Each planula sample was homogenized and filtered on a pre-combusted $25 \mathrm{~mm}$ GF/F filter. The food sources (unicellular algae, rotifers, and bacteria) were also sampled for isotopic analysis $(\mathrm{n}=2$ for each food source). The samples were washed with DDW and dried at $60^{\circ} \mathrm{C}$ for $24 \mathrm{~h}$.

Analytical procedure. All samples (including planulae and coral tissue on GF/F filters and bulk zooxanthellae) were analyzed using an elemental analyzer (Carlo Erba 1110) connected to a Finnigan MAT 252 isotope ratio mass spectrometer (IRMS). For the bulk zooxanthellae, we used 200 to $300 \mu \mathrm{g}$ of organic matter. Filters were sub-sampled by cutting out a portion $(1 / 16$ to $1 / 2$ according to the concentration of organic matter assessed by the filter's shade). The samples were combusted to complete oxidation followed by reduction reactions. The resulting mixture of gas products was carried on a continuous flow of helium through a gas chromatographic (GC) column, which separates the gas mixture into 2 peaks, and finally to the isotopic ratio mass spectrometer. $\mathrm{N}_{2}$ is the first gas that is analyzed, followed by analysis of $\mathrm{CO}_{2}$. All carbon measurements are reported in permil (\%o) units relative to international Vienna-Peedee Belemnite Limestone standards (V-PDB). The nitrogen measurements are reported relative to atmospheric nitrogen standard. Organic internal standards were used to evaluate the analytical error: glycine for carbon and nitrogen isotopes, cellulose for carbon isotopes, and acetanilid for percentage of carbon and nitrogen in organic samples. The precision of measurements was $0.05 \%$ for $\delta^{13} \mathrm{C}$ and $0.2 \%$ o for $\delta^{15} \mathrm{~N}$. The \%o values for each sample were calculated as:

$$
\delta X=\left(\frac{R_{\mathrm{x}}}{R_{\mathrm{st}}}-1\right) \times 1000
$$

where $R_{\mathrm{x}}$ is the sample's ${ }^{13} \mathrm{C} /{ }^{12} \mathrm{C}$ or ${ }^{15} \mathrm{~N} /{ }^{14} \mathrm{~N}$, and $R_{\mathrm{st}}$ is the ${ }^{13} \mathrm{C} /{ }^{12} \mathrm{C}$ or ${ }^{15} \mathrm{~N} /{ }^{14} \mathrm{~N}$ of the standard. Each sample 
was run in duplicate, and the average \%o values are reported.

Statistical analysis. To test for differences between planulae and parental colonies as well as the different treatments, we used $t$-test and analysis of variance (ANOVA). Assumptions of a normal distribution and homogeneity of variances were verified using the Kolmogorov-Smirnov test and the Cochran test. When homogeneity of variances did not exist, non-parametric analysis (i.e. Kruskal-Wallis ANOVA by ranks) was applied. Unless otherwise specified, mean values are presented \pm SE. Data were analyzed using STATISTICA 7 software (StatSoft).

\section{RESULTS}

\section{Planula larvae versus parental colonies}

Stylophora pistillata planulae had more negative $\delta^{13} \mathrm{C}$ values compared to animal fractions and zooxanthellae fractions isolated from parental colonies (1-way ANOVA, $\mathrm{p}<0.001)$. The planulae were the most depleted in ${ }^{13} \mathrm{C}$ and had an average $\delta^{13} \mathrm{C}$ value of $-15.30 \pm 0.17 \%$; the parental animal fraction gave an intermediate value of $-14.09 \pm 0.15 \%$, while the $\delta^{13} \mathrm{C}$ value of the parental algal fraction was least negative $(-13.10 \pm 0.20 \%$; Fig. 1). The coral animal fraction had the highest $\delta^{15} \mathrm{~N}$ value with $2.28 \pm 0.05 \%$ (1-way ANOVA, $\mathrm{p}<0.001$ ), which was more than twice that of the algal fraction and planulae $(1.03 \pm 0.08 \%$ and 0.99 $\pm 0.12 \%$, respectively; Fig. 1). S. pistillata planulae were characterized by a relatively high $\mathrm{C} / \mathrm{N}$ ratio with a value that was 2 -fold higher $(14.75 \pm 0.57)$ than that of the parental animal fraction $(7.01 \pm 0.16)$ and the algal fraction $(7.02 \pm 0.24$; Kruskal Wallis ANOVA by ranks p < 0.001) (Fig. 2). The relation between $\delta^{13} \mathrm{C}$ and $\mathrm{C} / \mathrm{N}$ ratios reveals that the planulae display a wide

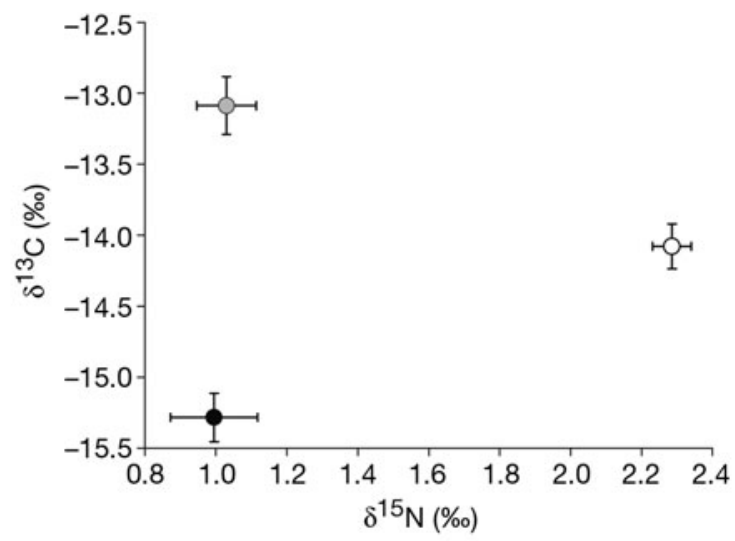

Fig. 1. Stylophora pistillata. $\delta^{13} \mathrm{C}$ versus $\delta^{15} \mathrm{~N}$ values (mean \pm $\mathrm{SE})$ of the animal fraction $(\mathrm{O} ; \mathrm{n}=21)$, zooxanthellae $(\mathrm{O} ; \mathrm{n}=$ $22)$, and bulk planulae $(\mathbf{n}=25)$

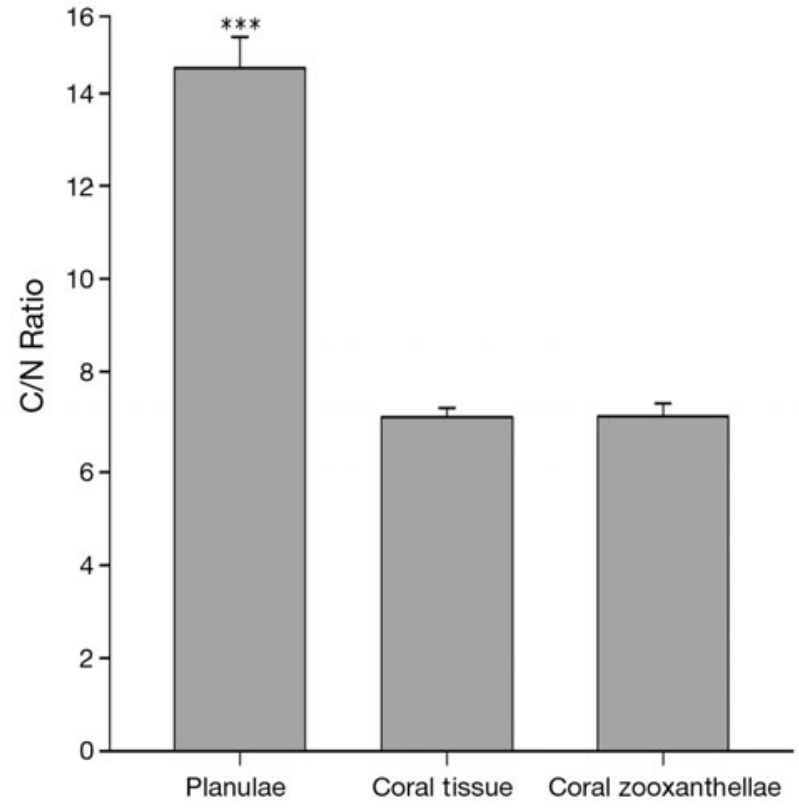

Fig. 2. Stylophora pistillata. C/N ratios (mean $\pm \mathrm{SE}$ ) of the animal fraction $(\mathrm{n}=21)$, zooxanthellae $(\mathrm{n}=22)$, and bulk planulae $(n=25)$. Asterisks represent statistically significant differences $\left({ }^{* * *} \mathrm{p}<0.001\right)$

range of $\delta^{13} \mathrm{C}$ and $\mathrm{C} / \mathrm{N}$ values while the coral parental animal fractions and algal fractions have a narrow $\mathrm{C} / \mathrm{N}$ range (between 5.5 and 8.5) (Fig. 3). Overall, the planulae have higher $\mathrm{C} / \mathrm{N}$ ratios, which are associated with depleted ${ }^{13} \mathrm{C}$ values. Following lipid extraction, no significant difference in $\delta^{13} \mathrm{C}$ values or in $\mathrm{C} / \mathrm{N}$ ratio was found between parental colonies and their planulae (paired $t$-test, $\mathrm{p}>0.05$ ) (Table 1). The chemical lipid extraction caused a depletion of $\sim 0.3 \%$ in ${ }^{15} \mathrm{~N}$ for both coral and planulae samples (Table 1).

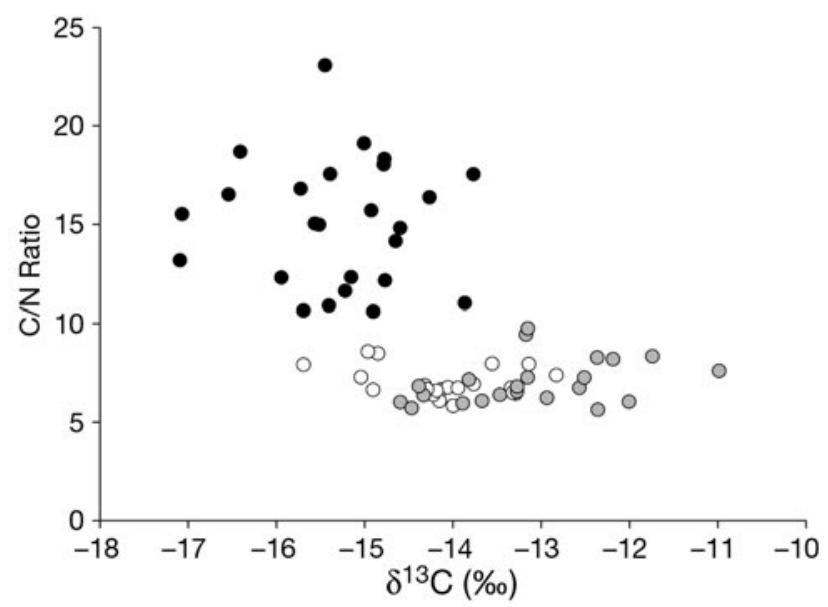

Fig. 3. Stylophora pistillata. $\mathrm{C} / \mathrm{N}$ ratio versus $\delta^{13} \mathrm{C}$ of the animal fraction $(O ; n=21)$, zooxanthellae $(O ; n=22)$, and bulk planulae $(\mathbf{n}=25)$ 
Table 1. Stylophora pistillata. Mean $\delta^{13} \mathrm{C}, \delta^{15} \mathrm{~N}$, and $\mathrm{C} / \mathrm{N}$ ratio values $\pm \mathrm{SE}$ of planulae and coral tissue prior to, and following, lipid extraction (sample size is indicated in parentheses). Asterisks represent statistically significant differences between coral and planulae for each parameter tested at each treatment $\left({ }^{*} \mathrm{p}<0.05,{ }^{* * *} \mathrm{p}<0.001\right.$; ns: non significant). Planulae collected from shallow water only

\begin{tabular}{|c|c|c|c|c|c|c|}
\hline & \multicolumn{3}{|c|}{ Bulk samples (prior to lipid extraction) } & \multicolumn{3}{|c|}{ Lipid-free samples (following lipid extraction) } \\
\hline & $\delta^{13} \mathrm{C}(\%)^{* * *}$ & $\left.\delta^{15} \mathrm{~N}(\%)\right)^{* * *}$ & $\mathrm{C} / \mathrm{N}$ ratio ${ }^{* * *}$ & $\delta^{13} \mathrm{C}(\%) \mathrm{ns}$ & $\delta^{15} \mathrm{~N}(\%)^{*}$ & $\mathrm{C} / \mathrm{N}$ ratio $\mathrm{ns}$ \\
\hline Coral & $\begin{array}{c}-14.09 \pm 0.15 \\
(\mathrm{n}=21)\end{array}$ & $\begin{array}{c}2.28 \pm 0.05 \\
(\mathrm{n}=21)\end{array}$ & $\begin{array}{c}7.01 \pm 0.16 \\
(\mathrm{n}=21)\end{array}$ & $\begin{array}{c}-17.19 \pm 0.45 \\
(\mathrm{n}=4)\end{array}$ & $\begin{array}{c}1.96 \pm 0.27 \\
(\mathrm{n}=4)\end{array}$ & $\begin{array}{c}4.82 \pm 0.19 \\
(\mathrm{n}=4)\end{array}$ \\
\hline Planulae & $\begin{array}{c}-15.3 \pm 0.17 \\
(\mathrm{n}=25)\end{array}$ & $\begin{array}{c}0.99 \pm 0.12 \\
(\mathrm{n}=25)\end{array}$ & $\begin{array}{c}14.75 \pm 0.57 \\
(\mathrm{n}=25)\end{array}$ & $\begin{array}{c}-15.88 \pm 0.30 \\
(\mathrm{n}=4)\end{array}$ & $\begin{aligned} 0.72 & \pm 0.46 \\
(\mathrm{n} & =4)\end{aligned}$ & $\begin{array}{c}3.9 \pm 0.14 \\
(\mathrm{n}=4)\end{array}$ \\
\hline
\end{tabular}

\section{Depth effect on $\delta^{13} \mathrm{C}$ values of planulae and parental coral colonies}

Coral animal and algal fractions of Stylophora pistillata became depleted in ${ }^{13} \mathrm{C}$ with depth (Fig. 4). Planulae collected from deep colonies $(20 \mathrm{~m})$ of $S$. pistillata exhibited lower $\delta^{13} \mathrm{C}$ values $(-16.96 \pm 0.26 \%$ compared to planulae released from shallow colonies $(-15.3 \pm 0.17 \%$; 1 -way ANOVA, p < 0.05) (Fig. 4). However, no significant differences were found in $\delta^{15} \mathrm{~N}$ $(0.36 \pm 0.32 \%$; $0.99 \pm 0.12 \%$ o) and $\mathrm{C} / \mathrm{N}$ ratio $(12.79 \pm$ $1.03 ; 14.74 \pm 0.57$ ) between deep and shallow planulae (1-way ANOVA, p >0.05).

\section{Effect of light on nutrition of planulae}

We found a significant effect of light on $\delta^{13} \mathrm{C}$ values of the planulae $(t$-test, $\mathrm{p}<0.001)$. Planulae kept in the light were able to photosynthesize and had a $\delta^{13} \mathrm{C}$

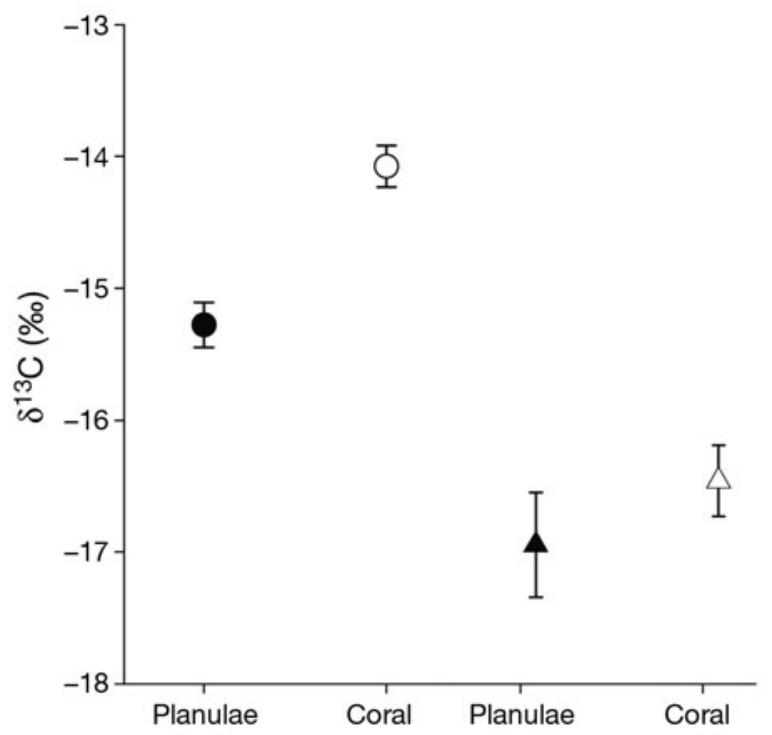

Fig. 4. Stylophora pistillata. $\delta^{13} \mathrm{C}$ values (mean $\pm \mathrm{SE}$ ) of planulae and adult coral colonies from $3 \mathrm{~m}(\boldsymbol{0} ; \mathbf{O})$ and $20 \mathrm{~m}$ $\left(\mathbf{\Delta}_{i} \Delta\right)$ depth value of $-15.68 \pm 0.17 \%$, similar to that of newly released planulae. Planulae that were kept in the dark showed high $\delta^{13} \mathrm{C}$ values of $-14.48 \pm 0.09 \%$ compared to planulae that were kept in ambient light (Table 2). A significant difference was also found between $\delta^{15} \mathrm{~N}$ values of light and dark treatments ( $t$-test, $\mathrm{p}<0.05$ ) (Table 2). Planulae kept in the dark were enriched in ${ }^{15} \mathrm{~N}(1.54 \pm 0.27 \%$ ), while those kept in the light had almost the same value $(0.69 \pm 0.11 \%)$ as in newly released planulae $(0.99 \pm 0.12 \% \mathrm{SD})$. In the dark, the $\mathrm{C} / \mathrm{N}$ ratio of planulae decreased significantly from an initial value of $14.75 \pm 0.57$ to $11.56 \pm 0.93$. However, planulae kept in the light maintained the same original $\mathrm{C} / \mathrm{N}$ ratio $(14.36 \pm 0.52)$ as newly released planulae ( $t$-test, $\mathrm{p}<0.05$ ) (Table 2).

\section{Feeding experiments - particulate food}

We found no significant difference in $\delta^{13} \mathrm{C}, \delta^{15} \mathrm{~N}$, and $\mathrm{C} / \mathrm{N}$ ratios between the different food treatments and the control (1-way ANOVA, p > 0.05) (Table 3).

\section{DISCUSSION}

Our study aimed at ascertaining the trophic biology of Stylophora pistillata larvae. We found significant differences in the carbon and nitrogen stable isotope compositions and in the $\mathrm{C} / \mathrm{N}$ ratios between larvae and parental coral colonies. These differences can be

Table 2. Stylophora pistillata. Mean $\delta^{13} \mathrm{C}, \delta^{15} \mathrm{~N}$, and $\mathrm{C} / \mathrm{N}$ ratio values \pm SE of planulae under light and dark conditions $(n=4)$. Asterisks represent statistically significant differences between dark and light treatments for each parameter tested $\left({ }^{*} \mathrm{p}<0.05\right.$,

$\left.{ }^{* * *} \mathrm{p}<0.001\right)$. Planulae collected from shallow water only

\begin{tabular}{|llll|}
\hline & $\left.\delta^{13} \mathrm{C}(\%)\right)^{* * *}$ & $\delta^{15} \mathrm{~N}(\%)^{*}$ & $\mathrm{C}^{*} \mathrm{~N} \mathrm{ratio}^{*}$ \\
\hline Light & $-15.68 \pm 0.17$ & $0.69 \pm 0.11$ & $14.36 \pm 0.52$ \\
Dark & $-14.48 \pm 0.09$ & $1.54 \pm 0.27$ & $11.56 \pm 0.93$ \\
\hline
\end{tabular}


Table 3. Mean $\delta^{13} \mathrm{C}$ and $\delta^{15} \mathrm{~N}$ values \pm SD of food types ( $\mathrm{n}=2$ for each food type) and Stylophora pistillata planulae subjected to different food types $(\mathrm{n}=3)$. ns: nonsignificant difference between planulae subjected to food treatments and control. Planulae collected from shallow water only

\begin{tabular}{|lrrrrr|}
\hline & \multicolumn{2}{c}{$\delta^{13} \mathrm{C}(\%)$} & & \multicolumn{2}{c|}{$\delta^{15} \mathrm{~N}(\%)$} \\
\cline { 2 - 3 } \cline { 5 - 6 } & Food type & Planulae (ns) & & Food type & Planulae (ns) \\
Nanochloropsis sp. & $-49.25 \pm 0.42$ & $-15.86 \pm 0.48$ & & $-3.62 \pm 0.10$ & $0.85 \pm 0.47$ \\
Rotifers & $-14.51 \pm 0.20$ & $-16.35 \pm 0.20$ & & $2.97 \pm 0.23$ & $1.15 \pm 0.09$ \\
Bacteria & $-21.54 \pm 0.23$ & $-15.04 \pm 0.35$ & & $2.58 \pm 0.79$ & $1.48 \pm 0.38$ \\
Control (no food) & & $-15.68 \pm 0.33$ & & $0.69 \pm 0.20$ \\
\hline
\end{tabular}

a loss of structural lipids (e.g. glycolipids, phospholipids), which are linked to proteins.

Our conclusions regarding the lipid reservoirs of Stylophora pistillata support previous work on planulae of a closely related species, Pocillopora damicornis. Richmond (1987) found that newly released planulae of $P$. damicornis contain $\sim 70 \%$ lipids. Stored lipids in marine plank-

attributed to one or more of the following factors: (1) isotopic fractionation during embryological development (Schwamborn et al. 2002), (2) different feeding behavior or food sources (DeNiro \& Epstein 1978), and (3) large differences in lipid content (DeNiro \& Epstein 1977, Post et al. 2007). S. pistillata planulae were found to be depleted in ${ }^{13} \mathrm{C}$ compared to parental coral tissue samples (i.e. both animal and algal fractions; Fig. 1). As the C/N ratio of $S$. pistillata larvae was twice that of the parental animal fraction (Fig. 2), we hypothesized that the depletion in ${ }^{13} \mathrm{C}$ was due to large differences in lipid content. The $\mathrm{C} / \mathrm{N}$ ratio is considered a good proxy for an organism's condition as it reflects the ratio of lipids and carbohydrates to proteins (Bodin et al. 2007). In addition, a strong correlation between the percentage of lipids (dry tissue weight) and $\mathrm{C} / \mathrm{N}$ ratio is reported for a range of marine and terrestrial animals (Post et al. 2007). In this study, where high $\mathrm{C} / \mathrm{N}$ ratios occurred we found lower $\delta^{13} \mathrm{C}$ values (Fig. 3), indicating that the extra carbon found in the larvae is depleted in ${ }^{13} \mathrm{C}$. Distinct molecule groups are known to differ in their isotopic ratios from the stable isotope composition of the bulk individuals. For example, lipids are depleted in ${ }^{13} \mathrm{C}$ compared to carbohydrates and protein (DeNiro \& Epstein 1977). This latter fact explains why lipid-enriched tissues/samples are generally more depleted in ${ }^{13} \mathrm{C}$ when compared to tissues that contain less fat (Sotiropoulos et al. 2004, Post et al. 2007). To confirm our hypothesis, lipid-extracted samples of adult coral colonies and their planulae were tested for stable isotope ratios. Following this procedure, no significant differences in $\delta^{13} \mathrm{C}$ and $\mathrm{C} / \mathrm{N}$ ratio values were found between planulae and parental coral colonies (Table 1). These results confirm our hypothesis that the differences found in $\delta^{13} \mathrm{C}$ and $\mathrm{C} / \mathrm{N}$ ratios between planula larvae and parental coral colonies originate in differences in the relative concentration of lipids. The chemical procedure of lipid extraction caused a non-significant decrease in the $\delta^{15} \mathrm{~N}$ values, both for corals and their planulae (Table 1). This phenomenon has been previously reported (Sotiropoulos et al. 2004, Sweeting et al. 2006, Ingram et al. 2007, Post et al. 2007) and has been explained as tonic larvae play an important role in buoyancy and in the animals' metabolism, since they serve as energetic reservoirs (Harii et al. 2007). Lipid-lean coral larvae are usually benthic (i.e. do not actively swim at the surface) due to lower proportions of wax esters. They are characterized by a relatively short competency period, enabling them to disperse over a limited geographic range (Ben-David Zaslow \& Benayahu 1996, Harii et al. 2002). According to Yamashiro et al. (1999), adult colonies of $S$. pistillata in Okinawa, Japan, contain $\sim 20 \%$ lipids of dry tissue weight. An increase in lipids is expected towards the reproductive season of the species (Leuzinger et al. 2003).

Most adult corals are considered 'mixotrophic' (acquiring organic materials both from their algal symbionts and from preying on zooplankton). Protein synthesis in corals is dependent upon heterotrophy for both nitrogen and phosphorus, which are limiting factors in an oligotrophic system (Anthony \& Fabricius 2000). On the other hand, lipid synthesis is primarily stimulated by light and carbon from photosynthesis (Crossland et al. 1980, Anthony \& Fabricius 2000). The increased heterotrophic capability of adult coral colonies is demonstrated by relatively high $\delta^{15} \mathrm{~N}$ values compared to the planulae (Fig. 1). $\delta^{15} \mathrm{~N}$ values increase with each trophic level in consumers (Minagawa \& Wada 1984). The fact that no difference was found in $\delta^{15} \mathrm{~N}$ values between the planulae and the algal symbionts isolated from parental colonies implies that the planulae derive their energy from photosynthates translocated from the photosynthetic endosymbionts. In addition, Titlyanov et al. (1998) reported degradation of zooxanthellae in Stylophora pistillata planulae. Those authors suggested that degradation of zooxanthellae in the planulae results from the digestion of their own symbionts, as in the case of adult polyps.

An unexpected finding in our study is that the $\delta^{15} \mathrm{~N}$ values reported for planulae and parental colonies of Stylophora pistillata are significantly lower compared to those of other coral species in the world (Muscatine \& Kaplan 1994, Muscatine et al. 2005; Figs. 1 \& 5) and also compared to different coral species sampled from the Gulf of Aqaba (Alamaru 2008). Moreover, Wild et 


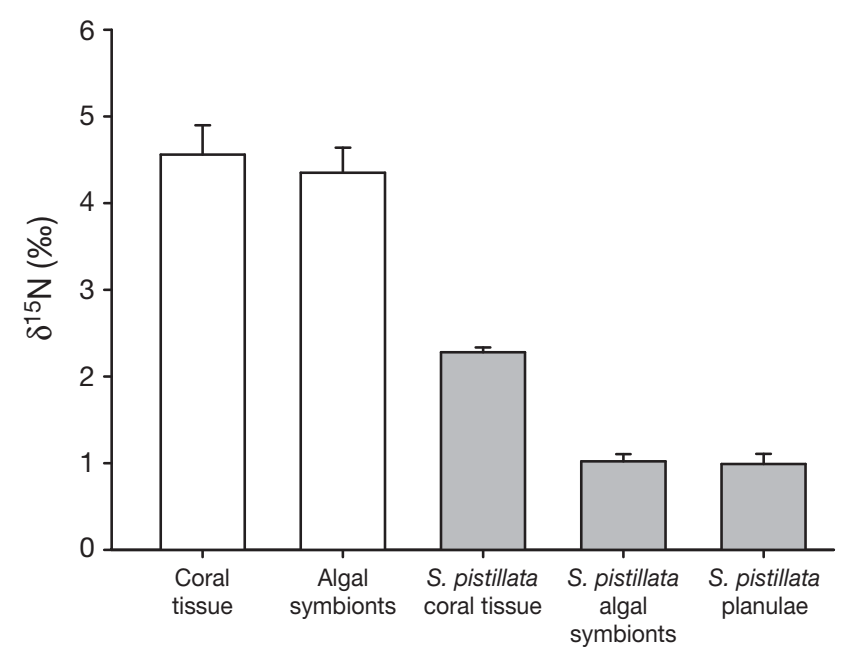

Fig. 5. $\delta^{15} \mathrm{~N}$ values (mean $+\mathrm{SE}$ ) of modern symbiotic corals from around the world. Average values of coral tissue $(n=17)$ and algal symbionts $(\mathrm{n}=18)$ are from Muscatine et al. (2005). Values of Stylophora pistillata animal fraction $(\mathrm{n}=21)$, algal fraction $(n=22)$, and planulae $(n=25)$ are from the present study

al. (2008) reported a value of $4.8 \pm 0.3 \%$ SD for planulae of $S$. pistillata collected in Australia during the mass spawning of 2005. This may indicate that the sources of nitrogen for both adult coral colonies and planulae are different compared to other coral species. The $\delta^{15} \mathrm{~N}$ values for $S$. pistillata algal symbionts in the Red Sea are close to $1 \%$ (Fig. 1), resembling values reported for the Caribbean coral Montastrea cavernosa, which contains symbiotic nitrogen-fixing cyanobacteria in its tissues (Lesser 2004, Lesser et al. 2007). Both our data for $S$. pistillata and the data published by Lesser et al. (2007) for M. cavernosa show that the zooxanthellae, but not the coral, use the products derived from nitrogen fixation (Fig. 1). This conclusion is based on the fact that the $\delta^{15} \mathrm{~N}$ value for atmospheric $\mathrm{N}_{2}$ is $0 \%$, while when dissolved in seawater it has a value of $\sim 1 \%$ o (Kayanne et al. 2005). The significantly low $\delta^{15} \mathrm{~N}$ values of the algal fraction of $S$. pistillata indicate the use of dissolved inorganic nitrogen (DIN) derived from nitrogen fixation. Recent analyses of $\delta^{15} \mathrm{~N}$ in corals over wide temporal and spatial scales revealed no similar isotopic signals (Heikoop et al. 2000, Swart et al. 2005a), except for samples of M. cavernosa. This hypothesis regarding the possible existence of nitrogen-fixing symbionts in $S$. pistillata remains to be tested in future work.

Muscatine et al. (1989) and Muscatine \& Kaplan (1994) demonstrated the effect of depth on $\delta^{13} \mathrm{C}$ and $\delta^{15} \mathrm{~N}$ values of both host coral tissue and symbiotic zooxanthellae. In their work, they noted depletion in the nitrogen and carbon isotopic composition in a variety of hermatypic coral species along a bathymetric gradient down to $50 \mathrm{~m}$. Our results show the same trend for Stylophora pistillata colonies and their planulae (Fig. 4). Deep corals are depleted in ${ }^{13} \mathrm{C}$ and shed depleted planulae compared to shallow-water colonies and planulae (Fig. 4). This finding indicates a strong relationship between the isotopic signatures of parental tissues and that of their planulae. This relation between parental tissues and their larvae could serve as an ecological tool to identify the depth origin of newly released coral larvae. Further research may confirm the reliability of this method for different species of corals. Rinkevich (1989) demonstrated that a significant proportion of carbon fixed by the zooxanthellae in the parental colony is incorporated into the planula larvae of $S$. pistillata. This may explain the resemblance in the isotopic signature of the parental colony seen in the planulae along the bathymetric gradient. The phenomenon of depletion along a bathymetric gradient is assumed to occur due to lower rates of photosynthesis in deeper water and to higher heterotrophy. According to the 'diffusion-depletion' hypothesis (D'Elia et al. 1983), in shallow water the photosynthesis rates are high and thus the metabolic carbon, which is believed to be the primary inorganic carbon source for the algal symbionts, is depleted and the supply of dissolved inorganic carbon (DIC) from sea water is limited by diffusion. In deep water, on the other hand, the photosynthetic rates are low and lead to greater isotopic fractionation. The fact that no difference was found in $\mathrm{C} / \mathrm{N}$ ratios between deep and shallow planulae may indicate a minimal energetic requirement for the production of gametes/larvae.

Richmond (1981) demonstrated the importance of the algal symbionts to larval energetics of the coral Pocillopora damicornis. He showed that 13 to $17 \%$ of the carbon fixed by the symbiotic zooxanthellae of the planulae during photosynthesis is translocated to the animal tissue of the larvae. In addition, Titlyanov et al. (1998) demonstrated that the photosynthetic rates of Stylophora pistillata planulae are close to those of adult polyps, strengthening the fact that algal symbionts are able to satisfy the nutritional needs of the planulae. Our results support those observations, showing that $S$. pistillata larvae, held for a period of 2 wk in the dark, started to consume their lipid and protein reservoirs, while planulae held in ambient light did not (Table 2). This consumption of stored energy in the form of lipids was expressed as an increase in $\delta^{13} \mathrm{C}$ and a decrease in the $\mathrm{C} / \mathrm{N}$ ratio (Table 2). The decrease in $\mathrm{C} / \mathrm{N}$ ratio is believed to indicate starvation (Schmidt et al. 1999, Okumura et al. 2002, Haubert et al. 2005). As lipids are depleted in ${ }^{13} \mathrm{C}$, during utilization of lipid reservoirs, animal tissues become relatively enriched in ${ }^{13} \mathrm{C}$ due to preferential loss of ${ }^{12} \mathrm{C}$ through respiration (Lajtha \& Michener 1994, Swart et al. 2005b). Fur- 
thermore, Swart et al. (2005b) explained the annual variability in $\delta^{13} \mathrm{C}$ values of respired $\mathrm{CO}_{2}$ as the result of seasonal differences in lipid respiration. It has been shown for a range of animals that in a situation of starvation, lipids are the primary source of the energy that is utilized (Limbourn et al. 2008).

Our results show enrichment in ${ }^{15} \mathrm{~N}$ due to starvation in the planulae kept in the dark (Table 2). An ongoing debate exists regarding the effect of starvation on $\delta^{15} \mathrm{~N}$ values in animals. Some papers have reported enrichment in ${ }^{15} \mathrm{~N}$ following a starvation period (GayeSiessegger et al. 2004, Fuller et al. 2005, Haubert et al. 2005, Gaye-Siessegger et al. 2007), while others reported no change in the isotopic ratios of nitrogen isotopes (Schmidt et al. 1999, Kempster et al. 2007). The enrichment in ${ }^{15} \mathrm{~N}$ is usually explained as a result of a change in the catabolic/anabolic equilibrium, which is a consequence of deamination of amino acids, derived from protein breakdown (Hobson et al. 1993). This finding strengthens the importance of photosynthesis to the developing planulae.

Our controlled feeding experiments demonstrated that despite the existence of an oral pore, Stylophora pistillata planulae do not actively feed on any of the provided food items (Table 3 ). We did not observe any feeding behavior throughout the feeding experiments, which confirms the isotopic analysis. These results notwithstanding, it is important to examine the possibility of the larvae feeding on other zooplankton species as food sources. There are several reports on planula larvae of sea anemones (Schwarz et al. 2002) and corals (Schwarz et al. 1999, Weis et al. 2001) that demonstrate acquisition of algal symbionts from the surrounding medium through the oral pore, when stimulated by the addition of Artemia sp. homogenate. However, these species are spawners, releasing their gametes into the surroundings. The resulting planulae usually require a longer developmental period in the water column prior to metamorphosis and settlement, compared to brooded larvae (Shlesinger \& Loya 1985). Therefore, it is reasonable to assume that planulae of spawners will require extrinsic food sources and/or a mechanism for zooxanthellae acquisition during their planktonic phase. The fact that in the present study no feeding behavior was observed in S. pistillata planulae may be explained by the differences in the reproductive strategy of this species that in turn affects its larval characteristics.

\section{CONCLUSIONS}

Our results demonstrate that Stylophora pistillata planulae are lecithotrophic and do not actively feed on the types of particulate food provided in these experi- ments. Their nutrition during the planktonic phase is exclusively based on photosynthates translocated from their algal endosymbionts. If indeed the oral pore does not have a feeding function at the planula stage, it is possible that at a later developmental stage, it facilitates swift metamorphosis to a primary polyp that can feed instantly. Although adult coral colonies can compensate for the lack of photosynthates from their zooxanthellae during bleaching through excess predation on zooplankton (Yamashiro et al. 2005, Grottoli et al. 2006), our results indicate that $S$. pistillata planulae are not able to do so. Following any disruption of the symbiosis, they will consume their internal lipid and protein reservoirs, thus decreasing their chances for successful recruitment. In light of increasing world-wide environmental and anthropogenic disturbances, our findings stress the importance of ensuring healthy adult colonies in order to produce viable, lipid-rich larvae that will be able to endure the hazardous path to metamorphosis.

Acknowledgements. We are grateful to E. Brokovich, O. Bronstein, and K. O. Amar for their endless support in the field; to I. Brailovsky for help with the mass spectrometer; to E. Kramarsky-Winter, N. Paz, and M. Sussman for editorial assistance; to 3 anonymous reviewers for insightful comments; and to The Interuniversity Institute of Eilat for the diving facilities. This research was supported by the Israel Science Foundation (ISF) and the Raynor Chair for Environmental Conservation Research to Y.L.

\section{LITERATURE CITED}

Alamaru A (2008) Trophic biology of corals - insights from lipids and stable isotopes analyses. MSc thesis, Tel Aviv University

Amar KO, Chadwick NE, Rinkevich B (2007) Coral planulae as dispersion vehicles: biological properties of larvae released early and late in the season. Mar Ecol Prog Ser 350:71-78

Anthony KRN, Fabricius KE (2000) Shifting roles of heterotrophy and autotrophy in coral energetics under varying turbidity. J Exp Mar Biol Ecol 252:221-253

Baird AH, Gilmour JP, Kamiki TM, Nonaka M, Pratchett MS, Yamamoto HH, Yamasaki H (2006) Temperature tolerance of symbiotic and non-symbiotic coral larvae. Proc 10th Int Coral Reef Symp, Okinawa, 4:38-42

Ben-David Zaslow R, Benayahu Y (1996) Longevity, competence and energetic content in planulae of the soft coral Heteroxenia fuscescens. J Exp Mar Biol Ecol 206:55-68

Benayahu Y, Achituv Y, Berner T (1989) Metamorphosis of an octocoral primary polyp and its infection by algal symbiosis. Symbiosis 7:159-169

Bodin N, Le Loc'h F, Hily C (2007) Effect of lipid removal on carbon and nitrogen stable isotope ratios in crustacean tissues. J Exp Mar Biol Ecol 341:168-175

> Crossland CJ, Barnes DJ, Borowitzka MA (1980) Diurnal lipid and mucus production in the staghorn coral Acropora acuminata. Mar Biol 60:81-90

deBoer ML, Krupp DA, Weis VM (2007) Proteomic and transcriptional analyses of coral larvae newly engaged in symbiosis with dinoflagellates. Comp Biochem Physiol D 2:63-73 
D'Elia CF, Domotor SL, Webb KL (1983) Nutrient uptake kinetics of freshly isolated zooxanthellae. Mar Biol 75:157-167

DeNiro MJ, Epstein S (1977) Mechanism of carbon isotope fractionation associated with lipid synthesis. Science 197:261-263

- DeNiro MJ, Epstein S (1978) Influence of diet on the distribution of carbon isotopes in animals. Geochim Cosmochim Acta 42:495-506

Edmunds PJ, Gates RD, Gleason DF (2001) The biology of larvae from the reef coral Porites astreoides, and their response to temperature disturbances. Mar Biol 139: 981-989

> Folch J, Lees M, Sloane Stanley GH (1957) A simple method for the isolation and purification of total lipids from animal tissues. J Biol Chem 226:497-509

Fuller BT, Fuller JL, Sage NE, Harris DA, O'Connell TC, Hedges REM (2005) Nitrogen balance and $\delta^{15} \mathrm{~N}$ : why you're not what you eat during nutritional stress. Rapid Commun Mass Spectrom 19:2497-2506

> Gaye-Siessegger J, Focken U, Muetzel S, Abel H, Becker K (2004) Feeding level and individual metabolic rate affect $\delta^{13} \mathrm{C}$ and $\delta^{15} \mathrm{~N}$ values in carp: implications for food web studies. Oecologia 138:175-183

Gaye-Siessegger J, Focken U, Abel H, Becker K (2007) Starvation and low feeding levels result in an enrichment of ${ }^{13} \mathrm{C}$ in lipids and ${ }^{15} \mathrm{~N}$ in protein of Nile tilapia Oreochromis niloticus. J Fish Biol 71:90-100

> Gleason D, Edmunds P, Gates R (2006) Ultraviolet radiation effects on the behavior and recruitment of larvae from the reef coral Porites astreoides. Mar Biol 148:503-512

> Golbuu Y, Richmond R (2007) Substratum preferences in planula larvae of two species of scleractinian corals, Goniastrea retiformis and Stylaraea punctata. Mar Biol 152: 639-644

Grottoli AG, Rodrigues LJ, Palardy JE (2006) Heterotrophic plasticity and resilience in bleached corals. Nature 440: 1186-1189

Harii S, Kayanne H, Takigawa H, Hayashibara T, Yamamoto M (2002) Larval survivorship, competency periods and settlement of two brooding corals, Heliopora coerulea and Pocillopora damicornis. Mar Biol 141:39-46

Harii S, Nadaoka K, Yamamoto M, Iwao K (2007) Temporal changes in settlement, lipid content and lipid composition of larvae of the spawning hermatypic coral Acropora tenuis. Mar Ecol Prog Ser 346:89-96

Harrigan JF (1972) The planula larva of Pocillopora damicornis: lunar periodicity of swarming and substratum selection behavior. PhD thesis, University of Hawaii, Honolulu

Haubert D, Langel R, Scheu S, Ruess L (2005) Effects of food quality, starvation and life stage on stable isotope fractionation in Collembola. Pedobiologia (Jena) 49:229-237

> Heikoop JM, Dunn JJ, Risk MJ, Tomascik T, Schwarcz HP, Sandeman IM, Sammarco PW (2000) $\delta^{15} \mathrm{~N}$ and $\delta^{13} \mathrm{C}$ of coral tissue show significant inter-reef variation. Coral Reefs 19:189-193

> Hirose M, Yamamoto H, Nonaka M (2008) Metamorphosis and acquisition of symbiotic algae in planula larvae and primary polyps of Acropora spp. Coral Reefs 27:247-254

Hobson KA, Alisauskas RT, Clark RG (1993) Stable nitrogen isotope enrichment in avian tissues due to fasting and nutritional stress: implications for isotopic analyses of diet. Condor 95:388-394

Ingram T, Matthews B, Harrod C, Stephens T, Grey J, Markel R, Mazumder A (2007) Lipid extraction has little effect on the $\delta^{15} \mathrm{~N}$ of aquatic consumers. Limnol Oceanogr Methods $5: 338-343$
Kayanne H, Hirota M, Yamamuro M, Koike I (2005) Nitrogen fixation of filamentous cyanobacteria in a coral reef measured using three different methods. Coral Reefs 24:197-200

Kempster B, Zanette L, Longstaffe F, MacDougall-Shackleton S, Wingfield J, Clinchy M (2007) Do stable isotopes reflect nutritional stress? Results from a laboratory experiment on song sparrows. Oecologia 151:365-371

Lajtha K, Michener RH (1994) Stable isotopes in ecology and environmental science. Blackwell Scientific Publications, Oxford

Lesser MP (2004) Experimental biology of coral reef ecosystems. J Exp Mar Biol Ecol 300:217-252

Lesser MP, Falcón LI, Rodríguez-Román A, Enríquez S, Hoegh-Guldberg O, Iglesias-Prieto R (2007) Nitrogen fixation by symbiotic cyanobacteria provides a source of nitrogen for the scleractinian coral Montastrea cavernosa. Mar Ecol Prog Ser 346:143-152

Leuzinger S, Anthony KRN, Willis BL (2003) Reproductive energy investment in corals: scaling with module size. Oecologia 136:524-531

Levy O, Appelbaum L, Leggat W, Gothlif Y, Hayward DC, Miller DJ, Hoegh-Guldberg O (2007) Light responsive cryptochromes from a simple multicellular animal, the coral Acropora millepora. Science 318:467-470

Lewis JB (1974) Settlement behavior of planulae larvae of the hermatypic coral Favia fragum (Esper). J Exp Mar Biol Ecol 15:165-172

Limbourn A, Babcock R, Johnston D, Nichols P, Knott B (2008) Post-settlement energy reserves in Panulirus cygnus: experimental effects of starvation on survival and nutritional condition. Mar Biol 153:445-456

Loya Y (1972) Community structure and species diversity of hermatypic corals at Eilat, Red Sea. Mar Biol 13:100-123

Loya Y (1976) The Red Sea coral Stylophora pistillata is an $\mathrm{r}$ strategist. Nature 259:478-480

McEdward LR (1997) Reproductive strategies of marine benthic invertebrates revisited: facultative feeding by planktotrophic larvae. Am Nat 150:48-72

Minagawa M, Wada E (1984) Stepwise enrichment of ${ }^{15} \mathrm{~N}$ along food chains: further evidence and the relation between ${ }^{15} \mathrm{~N}$ and animal age. Geochim Cosmochim Acta 48:1135-1140

Muscatine L, Kaplan IR (1994) Resource partitioning by reef corals as determined from stable isotope composition 2 . $\delta^{15} \mathrm{~N}$ of zooxanthellae and animal tissue versus depth. Pac Sci 48:304-312

> Muscatine L, Porter JW, Kaplan IR (1989) Resource partitioning by reef corals as determined from stable isotope composition 1. $\delta^{13} \mathrm{C}$ of zooxanthellae and animal tissue versus depth. Mar Biol 100:185-193

> Muscatine L, Goiran C, Land L, Jaubert J, Cuif JP, Allemand $\mathrm{D}$ (2005) Stable isotopes $\left(\delta^{13} \mathrm{C}\right.$ and $\left.\delta^{15} \mathrm{~N}\right)$ of organic matrix from coral skeleton. Proc Natl Acad Sci USA 102: 1525-1530

> Negri A, Vollhardt C, Humphrey C, Heyward A, Jones R, Eaglesham G, Fabricius K (2005) Effects of the herbicide diuron on the early life history stages of coral. Mar Pollut Bull 51:370-383

Nozawa Y, Harrison P (2007) Effects of elevated temperature on larval settlement and post-settlement survival in scleractinian corals, Acropora solitaryensis and Favites chinensis. Mar Biol 152:1181-1185

> Okumura T, Nagasawa T, Hayashi I, Sato Y (2002) Effects of starvation on RNA:DNA ratio, glycogen content, and C:N ratio in columellar muscle of the Japanese turban shell Turbo (Batillus) cornutus (Gastropoda). Fish Sci 68:306-312 
Olson RR, Olson MH (1989) Food limitation of planktotrophic marine invertebrate larvae: Does it control recruitment success? Annu Rev Ecol Syst 20:225-247

Pennisi E (2007) Spawning for a better life. Science 318:1712-1717

Post D, Layman C, Arrington D, Takimoto G, Quattrochi J, Montaña C (2007) Getting to the fat of the matter: models, methods and assumptions for dealing with lipids in stable isotope analyses. Oecologia 152:179-189

Richmond RH (1981) Energetic considerations in the dispersal of Pocillopora damicornis (Linnaeus) planulae. In: Gomez ED (ed) Proc 4th Int Coral Reef Symp, Manila, 2: 153-156

Richmond RH (1985) Reversible metamorphosis in coral planula larvae. Mar Ecol Prog Ser 22:181-185

Richmond RH (1987) Energetics, competency, and long-distance dispersal of planula larvae of the coral Pocillopora damicornis. Mar Biol 93:527-533

Rinkevich B (1989) The contribution of photosynthetic products to coral reproduction. Mar Biol 101:259-263

Rinkevich B, Loya Y (1979) The reproduction of the Red Sea coral Stylophora pistillata 1. Gonads and planulae. Mar Ecol Prog Ser 1:133-144

Rosenfeld M (2004) The isotopic composition of stony corals as environmental recorders. $\mathrm{PhD}$ thesis, Tel-Aviv University

Schmidt O, Scrimgeour CM, Curry JP (1999) Carbon and nitrogen stable isotope ratios in body tissue and mucus of feeding and fasting earthworms (Lumbricus festivus). Oecologia 118:9-15

Schwamborn R, Ekau W, Voss M, Saint-Paul U (2002) How important are mangroves as a carbon source for decapod crustacean larvae in a tropical estuary? Mar Ecol Prog Ser 229:195-205

Schwarz JA, Krupp DA, Weis VM (1999) Late larval development and onset of symbiosis in the scleractinian coral Fungia scutaria. Biol Bull (Woods Hole) 196:70-79

Schwarz JA, Weis VM, Potts DC (2002) Feeding behavior and acquisition of zooxanthellae by planula larvae of the sea anemone Anthopleura elegantissima. Mar Biol 140: $471-478$

Shlesinger Y, Loya Y (1985) Coral community reproductive patterns: Red Sea versus the Great Barrier Reef. Science 228:1333-1335

Sotiropoulos MA, Tonn WM, Wassenaar LI (2004) Effect of lipid extraction on stable carbon and nitrogen isotope analysis of fish tissues: potential consequences for food web studies. Ecol Freshw Fish 13:155-160

Strathmann RR (1985) Feeding and nonfeeding larval development and life history evolution in marine invertebrates. Annu Rev Ecol Syst 16:339-361

Editorial responsibility: Charles Birkeland,

Honolulu, Hawaii, USA
Swart PK, Saied A, Lamb K (2005a) Temporal and spatial variation in the $\delta^{15} \mathrm{~N}$ and $\delta^{13} \mathrm{C}$ of coral tissue and zooxanthellae in Montastraea faveolata collected from the Florida reef tract. Limnol Oceanogr 50:1049-1058

Swart PK, Szmant A, Porter JW, Dodge RE, Tougas JI, Southem JR (2005b) The isotopic composition of respired carbon dioxide in scleractinian corals: implications for cycling of organic carbon in corals. Geochim Cosmochim Acta 69:1495-1509

Sweeting CJ, Polunin NVC, Jennings S (2006) Effects of chemical lipid extraction and arithmetic lipid correction on stable isotope ratios of fish tissues. Rapid Commun Mass Spectrom 20:595-601

Titlyanov EA, Titlyanova TV, Loya Y, Yamazato K (1998) Degradation and proliferation of zooxanthellae in planulae of the hermatypic coral Stylophora pistillata. Mar Biol 130:471-477

> van Oppen M (2001) In vitro establishment of symbiosis in Acropora millepora planulae. Coral Reefs 20:200

> Webster NS, Smith LD, Heyward AJ, Watts JEM, Webb RI, Blackall LL, Negri AP (2004) Metamorphosis of a scleractinian coral in response to microbial biofilms. Appl Environ Microbiol 70:1213-1221

Weis V, Reynolds W, deBoer M, Krupp D (2001) Host-symbiont specificity during onset of symbiosis between the dinoflagellates Symbiodinium spp. and planula larvae of the scleractinian coral Fungia scutaria. Coral Reefs 20:301-308

> Wild C, Jantzen C, Struck U, Hoegh-Guldberg O, Huettel M (2008) Biogeochemical responses following coral mass spawning on the Great Barrier Reef: pelagic-benthic coupling. Coral Reefs 27:123-132

Wilkinson CR (1999) Global and local threats to coral reef functioning and existence: review and predictions. Mar Freshw Res 50:867-878

> Yamashiro H, Oku H, Higa H, Chinen I, Sakai K (1999) Composition of lipids, fatty acids and sterols in Okinawan corals. Comp Biochem Physiol B Biochem Mol Biol 122:397-407

> Yamashiro H, Oku H, Onaga K (2005) Effect of bleaching on lipid content and composition of Okinawan corals. Fish Sci 71:448-453

> Yetinson T, Shilo M (1979) Seasonal and geographic distribution of luminous bacteria in the eastern Mediterranean Sea and Gulf of Eilat. Appl Environ Microbiol 37: $1230-1238$

- Zakai D, Dubinsky Z, Avishai A, Caaras T, Chadwick NE (2006) Lunar periodicity of planula release in the reefbuilding coral Stylophora pistillata. Mar Ecol Prog Ser 311:93-102

Submitted: November 21, 2008; Accepted: February 4, 2009 Proofs received from author(s): April 28, 2009 